\title{
THE PLANT FERREDOXINS AND THEIR RELATIONSHIP TO THE EVOLUTION OF FERREDOXINS FROM PRIMITIVE LIFE
}

\author{
D. O. Hall, R. CAmmaCK and K. K. RaO \\ Department of Botany, University of London \\ King's College, London, UK
}

\begin{abstract}
The first few ferredoxins were isolated, more or less simultaneously, from Clostridum and spinach. These non-haem, iron-containing oxidoreductases had almost the same low redox potential and both could catalyse the photoreduction of NADP by chloroplasts, but differed in molecular wcight and in the number of iron atoms they contained. Since that time nearly forty more ferredoxins have been isolated from all classes of organisms. These fall into four categories containing respectively $2,4,6$ or 8 atoms of iron per molc. Numerous physical propertics have been determined and studies on circular dichroism, electron spin resonance, proton magnetic resonance and Mössbauer spectra have been especially valuable in giving an insight into the varying nature of the active centre of the different ferredoxins. The amino acid sequences of fourteen ferredoxins have been determined and together with the variation in function permit phylogenetic relationships to be determined. The experimental work leading to these results is covered in this review.
\end{abstract}

\section{INTRODUCTION}

The name ferredoxin was originally suggested by Mortenson et $a^{1}$ for an iron-containing protein which they isolated from the bacterium Clostridium pasteurianum and which functioned as an electron carrier in the phosphoroclastic reaction leading to hydrogen formation in this organism. About the same time Tagawa and Arnon ${ }^{2}$ isolated a non-haem iron protein with a low oxidation-reduction potential from spinach leaves which catalyzed the reduction of NADP to $\mathrm{NADPH}_{2}$ by illuminated chloroplasts. These authors also found that $\mathrm{Cl}$. pasteurianum ferredoxin could substitute for the spinach protein in the photoreduction of NADP. Though the spinach non-haem iron protein differed from baterial ferredoxin in iron content, in molecular weight and in visible absorption spectrum, the similarity of the two proteins in their low redox potentials (close to that of the hydrogen electrode) and in their interchangeability in the photo-reduction of NADP by chloroplasts, caused Tagawa and Arnon to propose that the term ferredoxin be extended to include all non-haeme iron proteins with anoxidation-reduction potential more negative than NADP. Proteins similar to spinach ferredoxin had previously been reported in the literature under various names such as the methaemoglobin reducing factor, photosynthetic pyridine nucleotide reductase (PPNR), red enzyme of Chlorella and so on. ${ }^{3}$ 
Table 1. Properties of ferredoxins

\begin{tabular}{|c|c|c|c|c|c|c|c|}
\hline & $\begin{array}{c}\mathrm{Fe} \text { or S } \\
\text { atoms } \mathrm{mol}^{-1}\end{array}$ & $\begin{array}{l}\text { Molecular } \\
\text { weight }\end{array}$ & $\begin{array}{c}\text { Number } \\
\text { of } \\
\text { amino } \\
\text { acids }\end{array}$ & $\begin{array}{c}\text { Redox } \\
\text { potential } \\
E_{0}^{\prime}, \mathrm{mV}\end{array}$ & $\begin{array}{l}\text { Number } \\
\text { of } \\
\text { electrons } \\
\text { transferred }\end{array}$ & $\begin{array}{c}\text { EPR } \\
\text { signal } \\
\text { (red. or ox.) } \\
\text { temp, K }\end{array}$ & Refs. \\
\hline $\begin{array}{l}8 \mathrm{Fe} \text { ferredoxins } \\
\text { Clostridium } \\
\text { (anaerobic fermentor) }\end{array}$ & 8 & 6000 & 55 & -395 & 2 & $\begin{array}{l}\text { red. } \\
15\end{array}$ & $76,77,2,16,78$ \\
\hline $\begin{array}{l}\text { Chlorobium } \\
\text { (green photosynthesizer) }\end{array}$ & 8 & 6000 & 56 & - & - & $\begin{array}{l}\text { red. } \\
15\end{array}$ & 79,73 \\
\hline $\begin{array}{l}\text { Chromatium } \\
\text { (red photosynthesizer) }\end{array}$ & 8 & 10000 & 81 & -490 & 2 & $\begin{array}{l}\text { red. } \\
15\end{array}$ & $79,62,80, \dagger$ \\
\hline $6 \mathrm{Fe}$ ferredoxins & 6 & 20000 & 171 & - & - & - & 81,83 \\
\hline (aerobic $\mathrm{N}_{2}$ fixer) & $6-7$ & 13000 & - & - & - & $\begin{array}{l}\text { ox. } \\
77\end{array}$ & \\
\hline $\begin{array}{l}\text { Rhodospirillum Type I } \\
\text { (red facultative photosynthesizer) }\end{array}$ & 6 & 8700 & 76 & - & - & - & 79 \\
\hline $\begin{array}{l}4 \mathrm{Fe} \text { ferredoxins } \\
\text { Desulphovibrio } \\
\text { (sulphate reducer) }\end{array}$ & 4 & 6000 & 56 & - & 1 & $\begin{array}{l}\text { red. } \\
<30 \text { ? }\end{array}$ & 66 \\
\hline $\begin{array}{l}\text { Bacillus polymyxa } \\
\text { (facultative } \mathrm{N}_{2} \text { fixer) }\end{array}$ & 4 & 9000 & - & -380 & 1 & $\begin{array}{l}\text { red. } \\
<30\end{array}$ & 67,68 \\
\hline $\begin{array}{l}\text { Beef heart mitochondria } \\
\text { (subunit of succinate dehydrogenase) }\end{array}$ & 4 & 70000 & - & - & - & $\begin{array}{l}\text { red. } * \\
103\end{array}$ & 84 \\
\hline $\begin{array}{l}\text { Chromatium HiPIP } \\
\text { (red photosynthesizer) }\end{array}$ & 4 & 9650 & 86 & +350 & 1 & $\begin{array}{l}\text { ox. } \\
77\end{array}$ & $64,65,85$ \\
\hline \multicolumn{8}{|l|}{$\begin{array}{l}2 \text { Fe ferredoxins } \\
\text { Bacterial }\end{array}$} \\
\hline $\begin{array}{l}\text { Clostridium EPR protein } \\
\text { (anaerobic } \mathrm{N}_{2} \text { fixer) }\end{array}$ & 2 & 24000 & - & - & 1 & $\begin{array}{l}\text { red. } \\
77\end{array}$ & 86,46 \\
\hline Clostridium ozoferredoxin & 2 & 27500 & - & - & - & $\begin{array}{l}\text { red. } \\
15 \text { ? }\end{array}$ & 87 \\
\hline
\end{tabular}


Clostridium hydrogenase

E. coli

Rhodospirillum Type II

(red photosynthesizer :

facultative aerobe)

Azotobacter Type I

(aerobic $\mathrm{N}_{2}$ fixer)

Azotobacter Type II

(aerobic $\mathrm{N}_{2}$ fixer)

Pseudomonas putida

(aerobic hydroxylator)

Plant

Microcystis

(blue-green alga)

Nostoc

(blue-green alga, $\mathrm{N}_{2}$ fixer)

Scenedesmus

(green alga)

Equisetum

(horsetail, primitive plant)

Spinacea

(higher plant)

Animal

Beef adrenal glands

(adrenodoxin)

Beef heart mitochondria

(Complex III Fe-S protein)

104 
In the early stages of the study of the ferredoxin two distinct types were recognised, the bacterial ferredoxins and the chloroplast ferredoxins. However, as we shall see later, with the availability of information regarding the chemical composition, amino acid sequence and physicochemical parameters of ferredoxins, and with the discovery of more than one ferredoxin in some organisms, it became necessary to revise this simple classification. Furthermore, proteins resembling ferredoxins in structure and composition were also obtained from mammalian sources. It is now recognised that the ferredoxins belong to the group known as iron-sulphur proteins (proteins which contain one or more atoms of non-haem iron bonded to cysteine or inorganic sulphur atoms) which are ubiquitous in nature. Since they occur in primitive bacteria, algae, higher plants and animals, ferredoxins are very good candidates for the study of biological evolution based on variations in amino acid sequences of homologous proteins. This technique has been applied in the phylogenetic classification of organisms from the primary structures of several proteins including cytochromes $c$, haemoglobins and fibrinopeptides ${ }^{4-8}$.

The main features of the ferredoxins are the presence of an active centre containing iron and sulphur, their low red ox potential $\left(E_{0}^{\prime}=c-0.4\right.$ volts), their participation in biological electron transport, and the formation of a characteristic epr signal centred around $g=1.94$ (in the reduced state) at very low temperatures, e.g. liquid nitrogen or liquid helium. The types of electron transfer reactions in which they participate are quite diverse, such as the Clostridia phosphoroclastic reaction, nitrogen fixation, nitrite reduction, photosynthesis and mammalian steroid hydroxylation ${ }^{9-11}$. Some properties of the various ferredoxins are listed in Table 1.

\section{EXTRACTION OF FERREDOXINS}

The ferredoxins characteristically contain a preponderance of acidic amino acids and therefore are readily adsorbed by the anion exchange resin DEAEcellulose. This property is well utilized in the isolation and purification of these proteins. The main steps involved in the isolation procedure are: (1) preparation of a cell-free extract and centrifugation to get rid of insoluble debris: (2) adsorption of ferredoxins from the supernatant by DEAEcellulose either on a column or by batchwise addition of the resin; (3) chromatographic elution of the ferredoxin from the DEAE-cellulose using a buffered sodium chloride gradient; (4) ammonium sulphate fractionation; and (5) gel filtration on Sephadex G-75 or Biogel P-10 12,13. Common contaminants in ferredoxins are nucleic acid derivatives which can be removed by protamine sulphate treatment, by treatment with nucleases or by chromatography on hydroxylapatite ${ }^{14}$. Many ferredoxins are sensitive towards heat and aerobic oxidation and so over long periods it is advisable to store these proteins in liquid nitrogen.

\section{THE PLANT-TYPE FERREDOXINS}

The plant-type ferredoxins are obtained from all oxygen-evolving photosynthetic organisms, from the blue-green algae up to higher vascular plants. 
Table 2. Amino acid composition of plant terredoxins

\begin{tabular}{|c|c|c|c|c|c|c|c|c|c|c|c|c|c|c|c|c|c|c|c|c|}
\hline & Lys & His & Arg & Trp & Asx & Thr & Ser & Glx & Pro & Gly & Ala & Cys & Val & Met & Ile & Leu & Tyr & Phe & Total & Ref. \\
\hline $\begin{array}{l}\text { Microcystis } \\
\quad \text { (blue-green alga) }\end{array}$ & 3 & 1 & 1 & 0 & 13 & 7 & 6 & 13 & 4 & 12 & 9 & 5 & 4 & 1 & 6 & 9 & 3 & 1 & 98 & 92 \\
\hline $\begin{array}{l}\text { Anacystis } \\
\text { (blue-green alga) }\end{array}$ & 3 & 1 & 1 & 0 & 15 & 12 & 7 & 11 & 3 & 6 & 12 & 6 & 9 & 0 & 5 & 7 & 5 & 2 & 105 & 97 \\
\hline $\begin{array}{l}\text { Bumelleriopsis } \\
\quad \text { (yellow-green alga) }\end{array}$ & 5 & 1 & 1 & 0 & 14 & 6 & 7 & 15 & 3 & 6 & 11 & 4 & 6 & 1 & 5 & 9 & 4 & 3 & 101 & 98 \\
\hline $\begin{array}{l}\text { Scenedesmus* } \\
\quad \text { (green alga) }\end{array}$ & 4 & 1 & 1 & 0 & 12 & 10 & 8 & 10 & 4 & 7 & 10 & 6 & 5 & 1 & 3 & 7 & 4 & 3 & 96 & 14 \\
\hline $\begin{array}{l}\text { Euglena } \\
\quad \text { (green alga) }\end{array}$ & 5 & 1 & 1 & 0 & 14 & 9 & 8 & 9 & 4 & 7 & 8 & 6 & 6 & 0 & 4 & 7 & 1 & 3 & 93 & 99 \\
\hline $\begin{array}{l}\text { Cladophora } \\
\quad \text { (green alga) }\end{array}$ & 7 & 1 & 2 & 0 & 10 & 8 & 7 & 16 & 3 & 7 & 12 & 2 & 7 & 2 & 3 & 9 & 4 & 1 & 101 & 100 \\
\hline $\begin{array}{l}\text { Equisetum } \\
\text { (primitive vascular plant) }\end{array}$ & 4 & 1 & 1 & 0 & 9 & 7 & 8 & 16 & 4 & 9 & 6 & 4 & 6 & 1 & 5 & 8 & 2 & 4 & 95 & 50 \\
\hline $\begin{array}{l}\text { Polystichum } \\
\text { (fern) }\end{array}$ & 4 & 2 & 1 & 0 & 14 & 6 & 8 & 9 & 5 & 9 & 7 & 5 & 5 & 2 & 6 & 7 & 3 & 4 & 97 & 101 \\
\hline $\begin{array}{l}\text { Zea mays } \\
\quad \text { (monocot, } \mathrm{C}_{4} \text { plant) }\end{array}$ & 3 & 2 & 1 & 1 & 13 & 5 & 8 & 14 & 4 & 8 & 8 & 4 & 10 & 0 & 5 & 8 & 5 & 1 & 100 & 102 \\
\hline $\begin{array}{l}\text { Cyperus } \\
\text { (nutsedge, } \mathrm{C}_{4} \text { plant) }\end{array}$ & 6 & 1 & 1 & 1 & 10 & 4 & 7 & 14 & 4 & 9 & 8 & 4 & 9 & 1 & 4 & 10 & 4 & 1 & 98 & 103 \\
\hline $\begin{array}{l}\text { Colocasia } \\
\quad(\text { taro, monocot })\end{array}$ & 5 & 1 & 1 & 1 & 10 & 6 & 8 & 15 & 4 & 9 & 6 & 5 & 10 & 0 & 4 & 6 & 4 & 2 & 97 & 104 \\
\hline $\begin{array}{l}\text { Amaranthus } \\
\text { (pigweed, } \mathrm{C}_{4} \text { plant) }\end{array}$ & 4 & 1 & 1 & 1 & 12 & 8 & 8 & 14 & 5 & 6 & 10 & 5 & 5 & 1 & 6 & 6 & 4 & 1 & 98 & 101 \\
\hline $\begin{array}{l}\text { Spinacea* } \\
\text { (spinach) }\end{array}$ & 4 & 1 & 1 & 1 & 13 & 8 & 7 & 13 & 4 & 6 & 9 & 5 & 7 & 0 & 4 & 8 & 4 & 2 & 97 & 94 \\
\hline $\begin{array}{l}\text { Medicago* } \\
\text { (alfalfa, lucerne) }\end{array}$ & 5 & 2 & 1 & 1 & 9 & 6 & 8 & 16 & 3 & 7 & 9 & 5 & 9 & 0 & 4 & 6 & 4 & 2 & 97 & 20 \\
\hline $\begin{array}{l}\text { Gossypium } \\
\text { (cotton) }\end{array}$ & 3 & 1 & 2 & 1 & 16 & 4 & 6 & 18 & 4 & 8 & 8 & 4 & 8 & 1 & 4 & 6 & 2 & 3 & 99 & 105 \\
\hline $\begin{array}{l}\text { Leucaena* } \\
\quad \text { (Koa ; tree) }\end{array}$ & 5 & 1 & 2 & 1 & 11 & 4 & 7 & 16 & 5 & 6 & 7 & 5 & 6 & 0 & 4 & 10 & 3 & 3 & 96 & 106 \\
\hline
\end{tabular}


They contain two atoms of iron and two of labile sulphur per molecule, about 97 amino acid residues and have a molecular weight of about 12000 daltons. They have a redox potential of about -0.43 volts and they transfer one electron at a time during biological reactions ${ }^{2}, 15,16$. The amino acid compositions of the plant ferredoxins available up to now are given in Table 2.

The major role of ferredoxins in the chloroplasts is to mediate the transfer of electrons from chlorophyll (or from the 'primary electron acceptor') to the flavoprotein enzyme, ferredoxin-NADP reductase, which in turn reduces NADP to $\mathrm{NADPH}_{2}$. Thus the ferredoxin catalyzes reduction of NADP to NADPH ${ }_{2}$ which forms part of the non-cyclic photophosphorylation pathway. Ferredoxin also acts as a catalyst in cyclic photophosphorylation $^{3}$ and in nitrite reduction in the chloroplasts ${ }^{17}$. The similarity of the ferredoxins in the physiological activity of all $\mathrm{O}_{2}$-evolving photosynthetic organisms was first observed by Mitsui and Arnon ${ }^{3}$ when they found that ferredoxin from the blue-green alga Nostoc functioned as effectively as spinach ferredoxin as a catalyst in the photoreduction of NADP by spinach chloroplasts. The activity of ferredoxins can be easily measured by adding catalytic amounts of the ferredoxin to an assay mixture containing spinach chloroplasts (washed to remove soluble ferredoxin) and NADP and measuring the rate of reduction of NADP to $\mathrm{NADPH}_{2}$ on illumination (monitored as increase in absorbance of the reaction mixture at $340 \mathrm{~nm}$ ) ${ }^{18}$. We have recently studied the chemical and spectroscopic properties of ferredoxins from the blue-green algae Microcystis and Spirulina and these are found to be similar to those of higher plant ferredoxins. These properties will be discussed in detail later.

\section{PHYSICAL PROPERTIES OF FERREDOXINS}

\section{Optical spectra}

The plant ferredoxins are red in colour and their optical spectra exhibit absorption maxima at about $465,420,330$ and $278 \mathrm{~nm}$ (see Figure 1). Their molar absorbance at $420 \mathrm{~nm}$ is about 9 to $10 \times 10^{3} 1 \mathrm{~cm}^{-1}$. The absorption of the protein in the visible region is mainly due to the iron sulphur chromophore group and is lost on treatment of ferredoxins with reagents which remove iron or sulphur, i.e. mersalyl, dipyridyl, dilute acids, etc. The iron and sulphur can be put back and biologically active ferredoxin reconstituted by chemical methods ${ }^{12,19}$. On reduction with sodium dithionite, 50 per cent of the visible absorption is lost but the original spectrum is restored on reoxidation by shaking in air. The optical absorption at $278 \mathrm{~nm}$ is partly due to the aromatic amino acid content of the ferredoxins and partly to the presence of the chromophoric group. The ratio $R$ of the absorption at $420 \mathrm{~nm}$ to that at $278 \mathrm{~nm}\left(R=A_{420} / A_{278}\right)$ is often characteristic for a particular ferredoxin and is taken as an index of the purity of the specimen. The $R$ values of pure ferredoxins vary from about 0.47 (e.g. spinach ferredoxin containing one Trp and four Tyr residues) to 0.75 (e.g. Equisetum ferredoxin with two Tyr and no Trp residues). The $R$ value decreases on exposure of ferredoxins to air and on long-term storage at room temperatures. In the case of alfalfa ferredoxin the decrease in $R$ value on aerobic exposure is attributed to a loss in the "labile sulphur content' ${ }^{20}$ while with spinach ferredoxin it is 


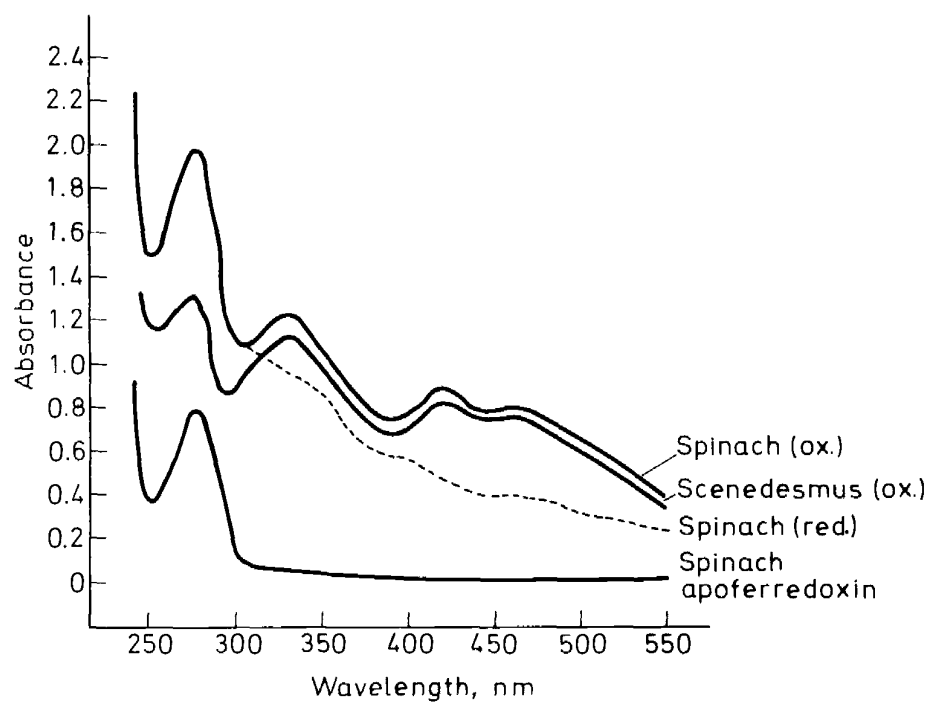

Figure 1. Absorption spectra of plant ferredoxins.

suggested that the labile sulphur atoms are oxidized to sulphur in the oxidation state zero covalently bound to protein ${ }^{21}$.

\section{Circular dichroism spectra}

Circular dichroism (CD) spectra are probably more sensitive than the optical absorption spectra of proteins to changes which are brought about in the overall conformation of proteins ${ }^{22}$. The $\mathrm{CD}$ spectra of oxidized and reduced ferredoxins from three different species are shown in Figure 2. The overall shape of the spectrum is similar for the three ferredoxins. However, a closer examination reveals minor changes in the position and shape of the absorption bands for the different species. For example, the major peak at $428 \mathrm{~nm}$ is shifted slightly towards the red in the ferredoxins of the lower order plants (Equisetum and Scenedesmus) as is the shoulder at $460 \mathrm{~nm}$. The shape of the major peak is slightly less wide in the Zea mays ferredoxin spectrum than that in the other two ferredoxins.

When we compared the spectra in a wide range of ferredoxins it was found that the spectra of the blue-green algal ferredoxins were all very similar, whereas those from higher plants showed greater variation in the detailed shape of the curves. The main absorption band around $428 \mathrm{~nm}$ in the CD spectra of ferredoxins is probably a reflection of the optical absorption at $420 \mathrm{~nm}$. All these CD bands are attributed to charge transfer in the two $\mathrm{Fe}^{3+}$ atoms bonded to sulphur in the chromophoric group. Slight differences in the nature of the $C D$ spectra in this region between various ferredoxins may be due to differences in the nature of the amino acid residues surrounding the chromophoric group. On reduction, the overall intensity of absorption decreases by about half, probably as a result of the 


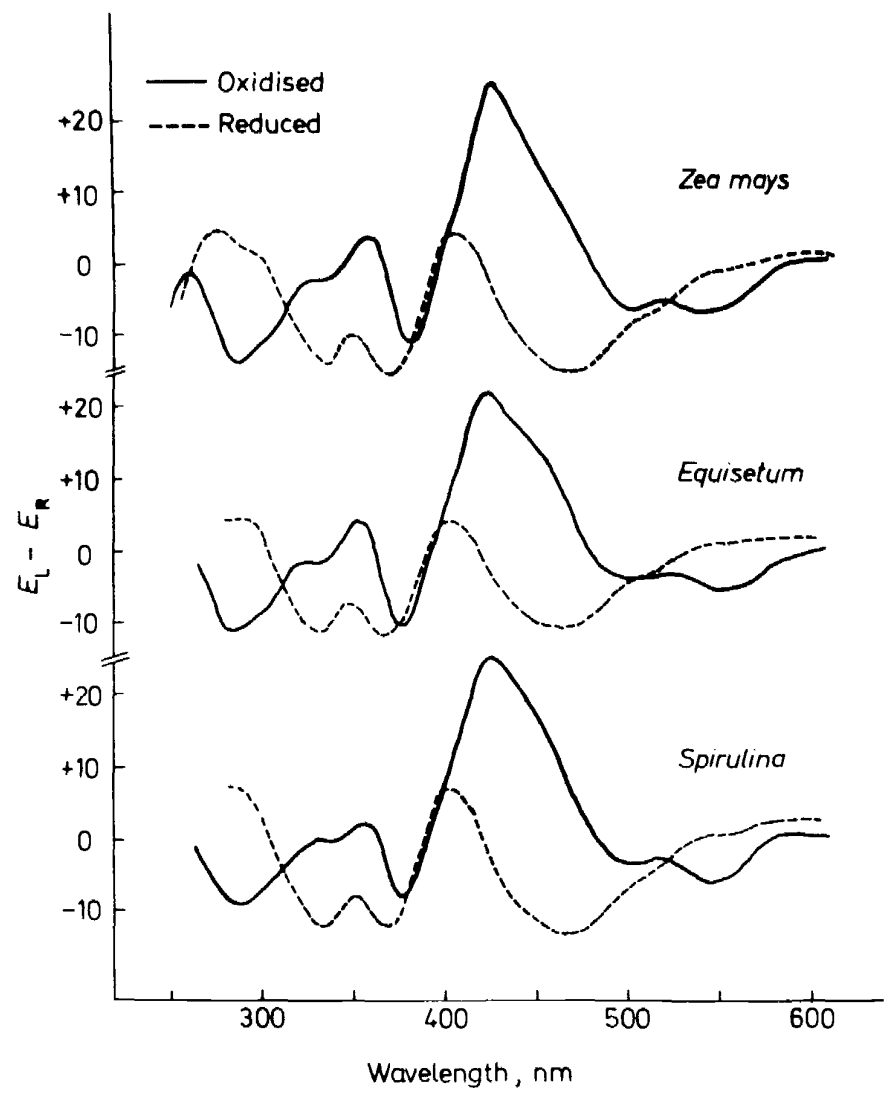

Figure 2. Circular dichroism of ferredoxins from three widely different plant species.

conversion of one $\mathrm{Fe}^{3+}$ to $\mathrm{Fe}^{2+}$, which has a much smaller tendency to show charge transfer absorption in this region. The CD spectrum of apo-ferredoxin shows no absorption in the visible region.

Garbett $e t a^{22}{ }^{22}$ were the first to detect an effect of $8 \mathrm{M}$ urea on the CD and ORD spectra of spinach ferredoxin. This was studied in further detail by other groups ${ }^{23} 25$. The process is complex. The first stage appears to be the conversion of ferredoxin to a form with a different protein configuration, and can be reversed by decreasing the concentrations of urea, or by adding $1 \mathrm{M} \mathrm{NaCl}$. Similar antagonism between the effects of urea and $\mathrm{NaCl}$ were observed in the epr spectrum by Cammack et $a l^{25}$. These changes in protein conformation may be similar to those which cause changes in the optical absorption and $\mathrm{CD}$ when ferredoxin forms a complex with ferredoxin NADP reductase $26,27$.

Eaton $e t a l^{28}$ have investigated the nature of the iron sulphur complex in spinach ferredoxin and adrenodoxin by observing the CD and optical spectra in the near IR wavelength region. They identified $d \rightarrow d$ transitions of the iron atoms in the spectra of the reduced proteins at about $4000 \mathrm{~cm}^{-1}$ 
and $6000 \mathrm{~cm}^{-1}$ and from the low energy of these transitions have concluded that the reduced iron-sulphur proteins contain a high spin ferrous ion in a distorted tetrahedral sitc.

\section{Electron paramagnetic resonance spectra}

One of the important physical properties of plant ferredoxins is that in the reduced state, and at low temperatures, they all exhibit an electron paramagnetic resonance (epr) spectrum centred around $y=1.94$. The signal is characteristic of iron sulphur proteins and the appearance of the signal (at temperatures ranging from liquid nitrogen to liquid helium) is used as a sensitive test to detect the presence of iron-sulphur proteins in whole cells and in cell-free preparations ${ }^{9-11}$. Palmer and Sands $^{29}$ and Hall et $a{ }^{30}{ }^{30}$ showed that spinach ferredoxin when reduced with excess dithionite exhibited an epr signal centred at $g=1.94$. Orme-Johnson and Beinert $^{31}$, by a series of anaerobic reductive titrations performed on a variety of iron-sulphur proteins, have shown that ferredoxins containing two iron atoms accept one electron on reduction; they also summarize other evidence for this stoichiometry.

The epr spectra of reduced plant ferredoxins exhibit orthorhombic symmetry. Typical spectra of two reduced ferredoxins are shown in Figure 3 and the apparent $g$-values of a range of plant ferredoxins are given in Table 3 .

Table 3. Principal apparent g-values of plant ferrodoxins at $77 \mathrm{~K}$

\begin{tabular}{lccc}
\hline Ferrcdoxin & $g_{x}$ & $g_{y}$ & $g_{z}$ \\
\hline Spinach & 1.886 & 1.946 & 2.041 \\
Parsley & 1.893 & 1.948 & 2.039 \\
Alfalfa & 1.888 & 1.948 & 2.040 \\
Maize & 1.889 & 1.948 & 2.043 \\
Equisetum & 1.883 & 1.948 & 2.045 \\
Scenedesmus & 1.882 & 1.947 & 2.037 \\
Bumilleriopsis & 1.885 & 1.948 & 2.044 \\
Microcystis & 1.884 & 1.947 & 2.040 \\
Anabaena & 1.883 & 1.947 & 2.042 \\
Spirulina & 1.880 & 1.949 & 2.045 \\
\hline
\end{tabular}

Pure specimens of oxidized ferredoxin exhibit no epr signal since it is nonmagnetic. The similarity in the shape of the epr spectra from two such diverse plant species as parsley and Spirulina (Figure 3), and the nearness of the $g$-value parameters for so many ferredoxins is again indicative of the identity of the nature of the active centre of all these ferredoxins. The role of the iron and sulphur atoms at the active centre in the generation of the epr signal has been confirmed by a number of independent studies. A small broadening was observed in the epr spectrum of reduced ${ }^{57} \mathrm{Fe}$ substituted plant ferredoxins probably due to nuclear hyperfine interactions ${ }^{12,32,33}$. Fee and Palmer ${ }^{34}$ replaced the labile sulphur of parsley ferredoxin with selenium isotopes and found that the shape of the epr spectrum of the selenium-substituted protein was different from that of the native protein 


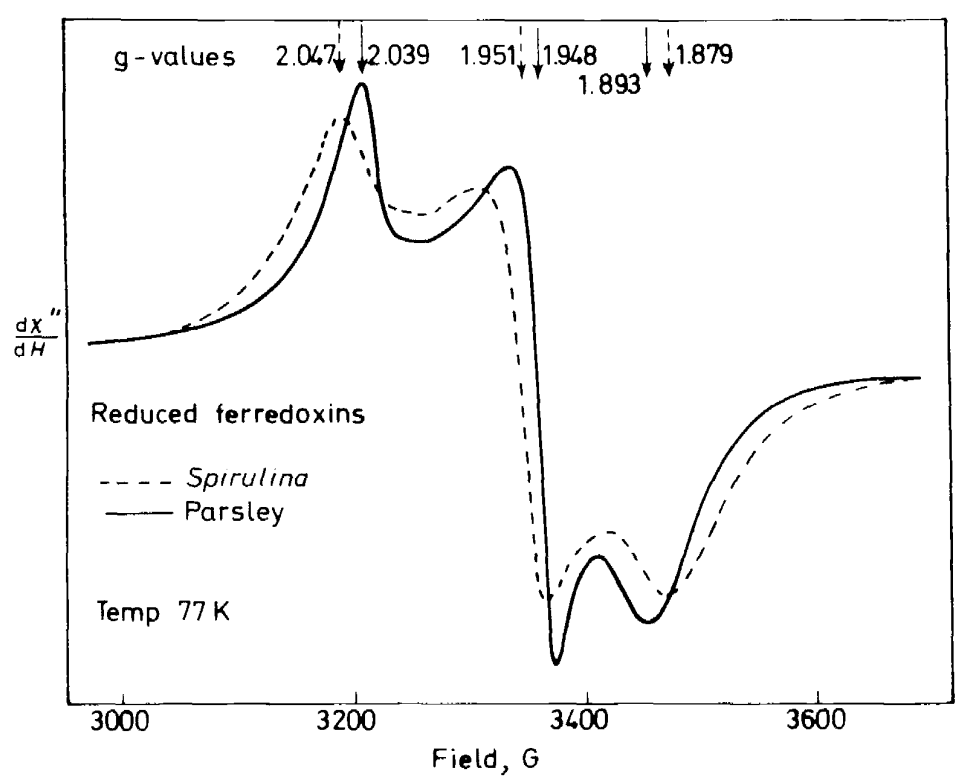

Figure 3. EPR spectra at $77 \mathrm{~K}$ of two reduced plant ferredoxins, illustrating the small variation in spectral shape which is observed. Other conditions of measurement were microwave frequency $9.17 \mathrm{GHz}$ : modulation amplitude $4 \mathrm{G}$.

and tended toward axial symmetry, with a substantially narrower line width in the $g_{z}$ region. This observation lends support to the view that the sulphur moiety of ferredoxin also contributes to the generation of the epr signals. Similar studies have been performed with adrenodoxin, putidaredoxin and the iron-sulphur proteins from Azotobacter vinelandii to establish the participation of iron and labile sulphur atoms in the production of the epr signal ${ }^{35}$.

The shape and intensity of the epr signals of reduced plant ferredoxins are affected by the environment of the protein in solution. Thus Fee and Palmer ${ }^{34}$ observed a broadening of the epr spectrum of parsley ferredoxin by chloride ions but not by sulphate or other salts. Parsley ferredoxin is the only ferredoxin in which this effect has been observed. The shape of the spectrum of reduced spinach ferredoxin in low concentrations was affected by the presence of urea up to a concentration of $5 \mathrm{M}$, the $g_{\mathrm{z}}$ and $g_{\mathrm{y}}$ values moving slightly to higher magnetic fields and the $g_{\mathrm{x}}$ value moving downfield ${ }^{24}$. The ferredoxin is unstable in these conditions: unless care is taken to keep the ferredoxin urea mixture perfectly anaerobic before reduction, the intensity of the epr signal decreases by as much as 50 per cent for a solution of spinach ferredoxin in $7.5 \mathrm{M}$ urea. Coffman and Stevens ${ }^{36}$ found that the shape of the spectrum of reduced spinach ferredoxin in the presence of organic solvents like methanol tended towards axial symmetry. Similar changes in the epr spectral characteristics of ferredoxins were observed by treating ferredoxins with various concentrations of chaotropic agents, of 


\section{EVOLUTION OF PLANT FERREDOXINS}

which urea is one example ${ }^{25}$. On adding low concentrations of the agents, e.g. $0.04 \mathrm{M}$ trichloroacetate, to reduced Spirulina ferredoxin there were decreases in the linewidth and small shifts in the apparent $g$-values until it resembled more closely that of parsley ferredoxin (Figure 4). The effect is reversed on adding $2 \mathrm{M} \mathrm{NaCl}$. It therefore seems that there is a balance between

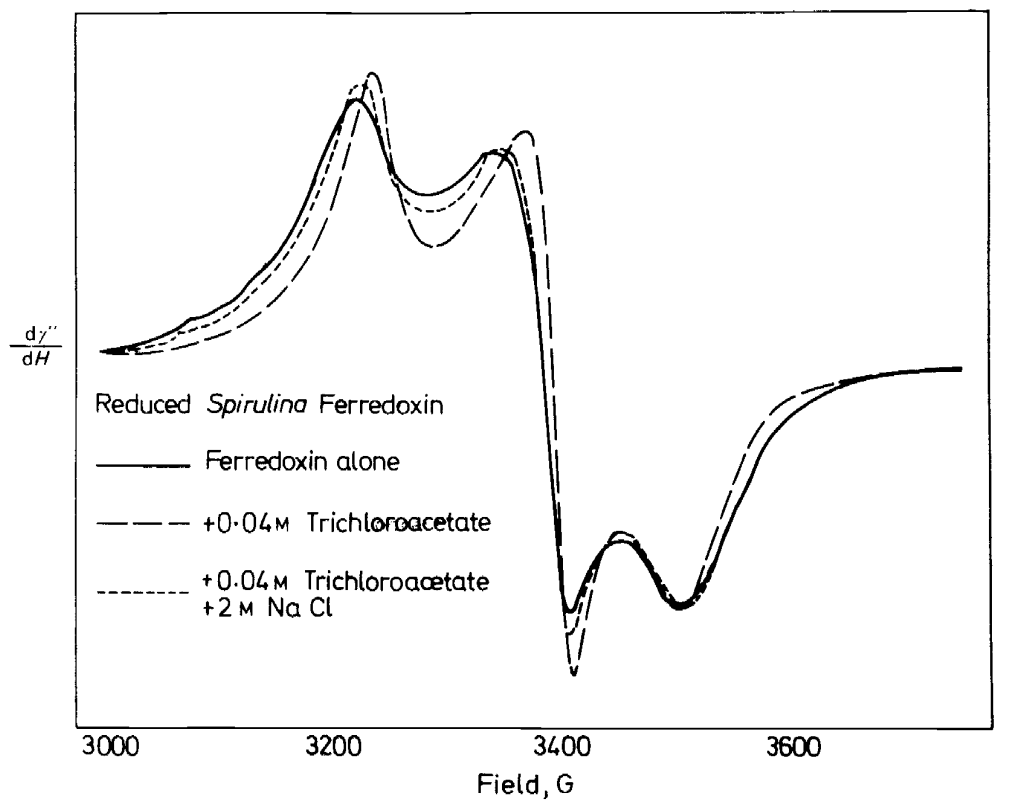

Figure 4. EPR spectra of Spirulina ferredoxin illustrating the effect of low concentrations of a chaotropic agent, and the reverse eflect of $\mathrm{NaCl}$. Conditions of measurement as in Figure 3.

the 'sharpening' effect of chaotropic agents, and the 'broadening' effect of chloride. Since ferredoxins are more stable in the presence of chloride it is tempting to speculate that those ferredoxins which have a broader epr spectrum in the reduced state are more stable than those with narrower line widths under equivalent conditions of salt concentration. Thus a comparison of the epr spectra of reduced parsely and Spirulina ferredoxins clearly shows that parsley ferredoxin has narrower linewidths (Figure 3) and therefore should be more sensitive to denaturing agents than the blue-green algal ferredoxin. Comparative stability studies ${ }^{37}$ have shown that Spirulina ferredoxin is much more stable at room temperature than parsley ferredoxin (Table 4). Since the chromophoric groups in the two ferredoxins are identical, the reason for the differcnce in stabilities should be found in the differences in the amino acid compositions of these proteins.

The real cause of the induced changes in the epr spectral characteristics 
D. O. HALL. R. CAMMACK AND K. K. RAO

Table 4. Relative activities of plant ferredoxins after storage for two months ${ }^{37}$

\begin{tabular}{lcc}
\hline \multicolumn{1}{c}{ Species } & \multicolumn{2}{c}{$\%$ \% of original activity } \\
& Liquid $\mathrm{N}_{2}$ & Room temperature $(21 \mathrm{C})$ \\
\hline Spirulina & 93 & 35 \\
Scenedesmus & 79 & 5 \\
Spinach & 81 & 3 \\
Alfalfa & 78 & 8 \\
Parsley & 74 & 3 \\
Zea mays & 81 & 15 \\
\hline
\end{tabular}

of reduced ferredoxins by chloride ions, organic solvents and chaotropic agents is not yet definitely known. No corresponding changes have been observed in the CD or pmr spectra of the reduced ferredoxins in solution. One possible explanation is that the spectra were measured in frozen samples and the reagents might have induced small changes in the spectra by alteration of the structure of the ice around the ferredoxin molecule. On adding higher concentrations of chaotropic agents such as guanidine hydrochloride the epr spectrum undergoes a more dramatic change, which again is reversible ${ }^{25}$. This may be related to the changes in protein conformation which are seen in the $C D$.

As early as 1966 Gibson et al ${ }^{38}$ and Thornley et $a l .{ }^{39}$ proposed a model for the active centre of plant ferredoxins, based on epr studies and the magnetic susceptibility data then available. According to their postulate the two iron atoms in oxidized ferredoxin are high spin ferric antiferromagnetically coupled to give a net spin of zero and no epr signal; on reduction one

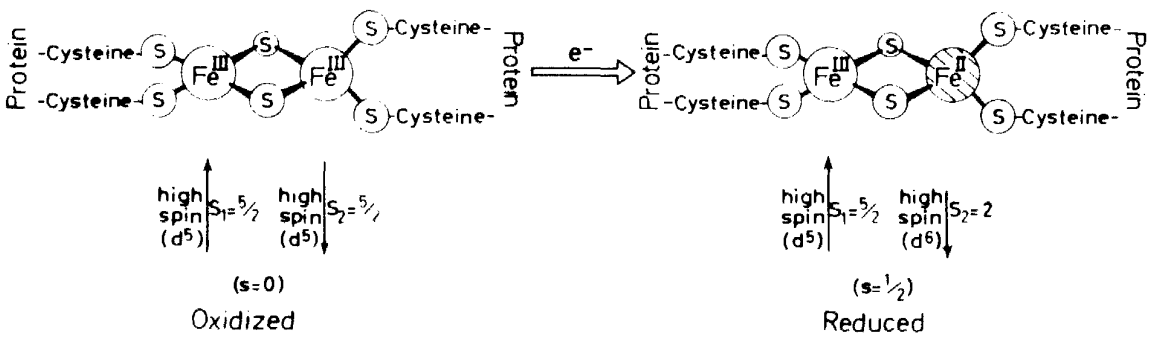

Figure 5. Model for the iron -sulphur group of oxidized and reduced plant ferredoxins ${ }^{12}$.

of the iron atoms accepts an electron and becomes high spin ferrous to give a net spin of $S=\frac{1}{2}$ and gives the characteristic epr signal (Figure 5).

\section{Mössbauer spectra}

The Mössbauer effect is a very useful tool to study the nature of the iron atoms in protein $s^{40.41}$. Since it is not a magnetic resonance technique it 


\section{EVOLUTION OF PLANT FERREDOXINS}

can be observed equally well in paramagnetic (e.g. reduced ferredoxin) and non-magnetic (e.g. oxidized ferredoxin) materials. The Mössbauer effect can be used to measure the effective magnetic field produced at the nuclei by the electrons. Two parameters measured by Mössbauer spectroscopy are the chemical isomer shift $(\delta)$ which gives an idea of the valence and spin state of the iron atom and its degree of covalency, and the quadrupole splitting $(\Delta E)$ which is a probe of the local stereochemistry of the iron atom. Considerably more information regarding the valence and spin state of the iron can be obtained from the magnetic hyperfine spectra observed at low temperatures when the Mössbauer effect is studied in the presence and absence of an external magnetic field ${ }^{42}$.

Since the Mössbauer effect in the case of iron is specific to ${ }^{57} \mathrm{Fe}$ nuclei and since the natural abundance of ${ }^{57} \mathrm{Fe}$ nuclei in iron is very low (about 2.2 per cent) it is advantageous to enrich the ferredoxins with ${ }^{57} \mathrm{Fe}$ before Mössbauer effect measurements. This can be easily achieved by chemical substitution in the case of ferredoxins without changing the conformation or biological activity of the protein. Enrichment with ${ }^{57} \mathrm{Fe}$ has also been achieved by growing Euglena on ${ }^{57} \mathrm{Fe}$ and then extracting the enriched ferredoxin ${ }^{44}$. The results were very similar to those from the chemically substituted ferredoxin.

The Mössbauer spectra of three plant ferredoxins in the reduced state at two different temperatures are shown in Figure 6. The spectrum of the

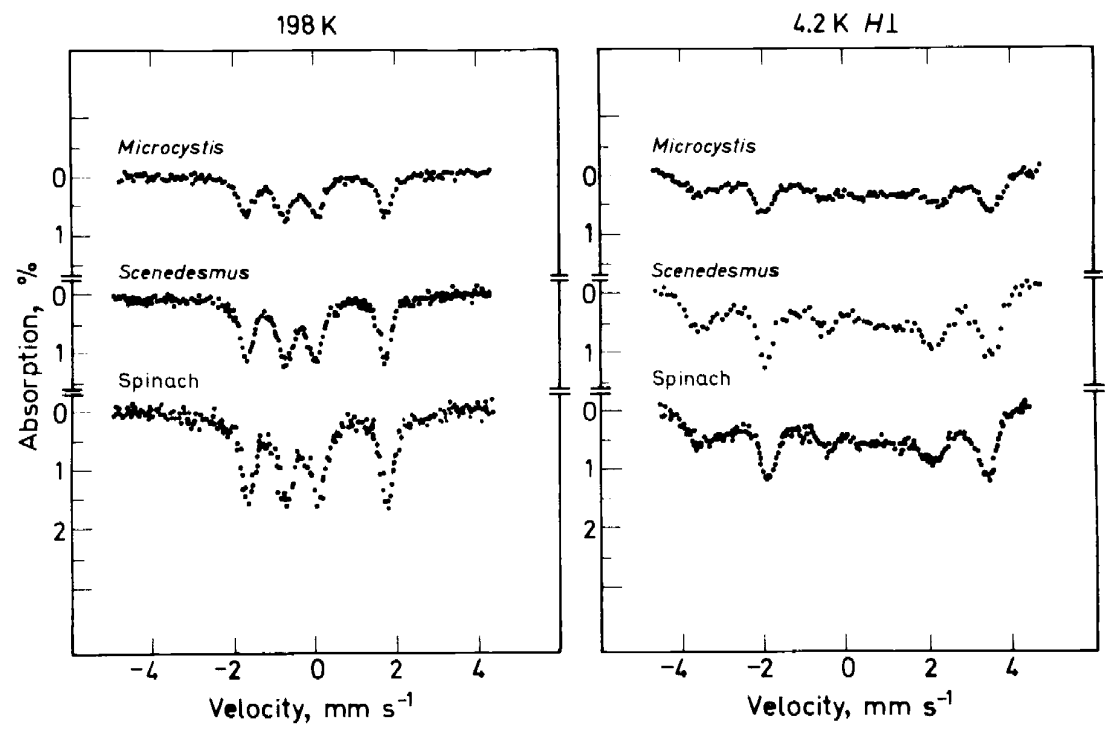

Figure 6. Mössbauer spectra of reduced ferredoxins from two algal and one plant species, at $198 \mathrm{~K}$ (left), and at $4.2 \mathrm{~K}$ (right) in a small field perpendicular to the $\gamma$-rays, illustrating the magnetic hyperfine splitting ${ }^{92}$. 
oxidized ferredoxins (not shown in the diagram) has two lines of almost equal width with a chemical shift of about $+0.20 \mathrm{~mm} \mathrm{~s}^{-1}$ relative to
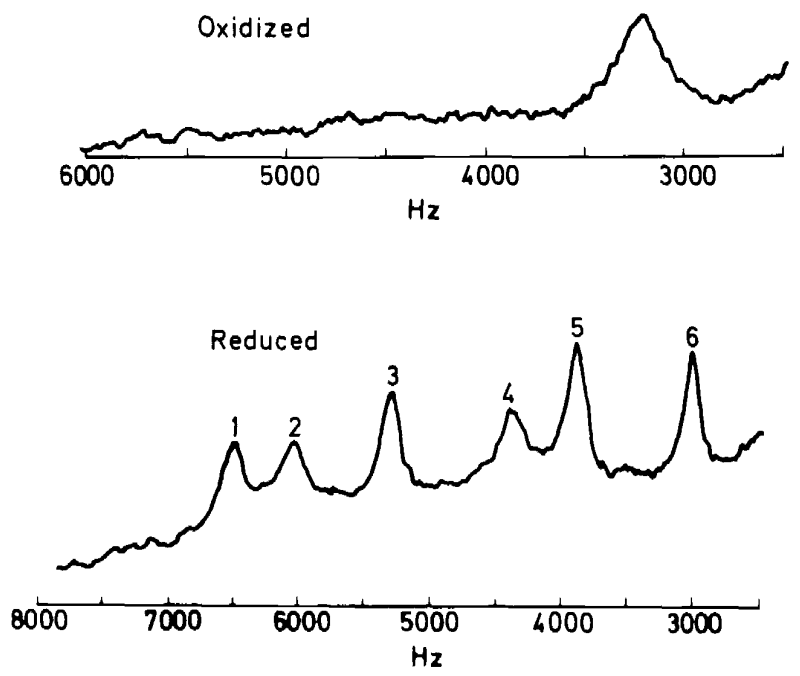

Figure 7. Low-field region of the pmr spectra of Scenedesmus ferredoxin, $\mathrm{D}_{2} \mathrm{O}, 22 \mathrm{C}$. In the reduced form, the resonances due to six protons are visible and the peaks are numbered. (Unpublished results obtained in collaboration with W. D. Phillips and C. C. McDonald).

metallic iron and a quadrupole splitting of $0.60 \mathrm{~mm} \mathrm{~s}^{-1}$. The spectrum is consistent with the high-spin $\mathrm{Fe}^{3+}$ atoms in almost equivalent states. The spectra of the reduced ferredoxins at high temperature (Figure 6) show four lines of almost equal width and depth. These are a superposition of two quadrupole split doublets; one doublet similar to that of the oxidized ferredoxin $\left(\mathrm{Fe}^{3+}\right)$ and the second with a larger chemical shift and quadrupole splitting which is characteristic of the high-spin $\mathrm{Fe}^{2+}$ atom.

The effect of a small magnetic field on the Mössbauer spectrum of reduced ferredoxin at very low temperatures showing magnetic hyperfine splitting is shown on the right hand side of Figure 6. The Mössbauer spectrum is split by the application of large magnetic fields, the effective field of the $\mathrm{Fe}^{3+}$ ions decreasing and that of the $\mathrm{Fe}^{2+}$ ions increasing in the applied field. The details of the interpretation of the Mössbauer spectra are given elsewhere $^{45}$ : suffice it to say that the resemblance of the spectra of ferredoxins from spinach, Scenedesmus and Microcystis again confirms the view that the active centres of all plant ferredoxins are identical in structure. Mössbauer studies have also been carried out on parsley, spinach and other ferredoxins by Dunham et $a l^{46}$ All these studies confirm the original model of Gibson ${ }^{38}$, Thornley $^{39}$ and associates proposed for the active centre of ferredoxins (Figure 5). 


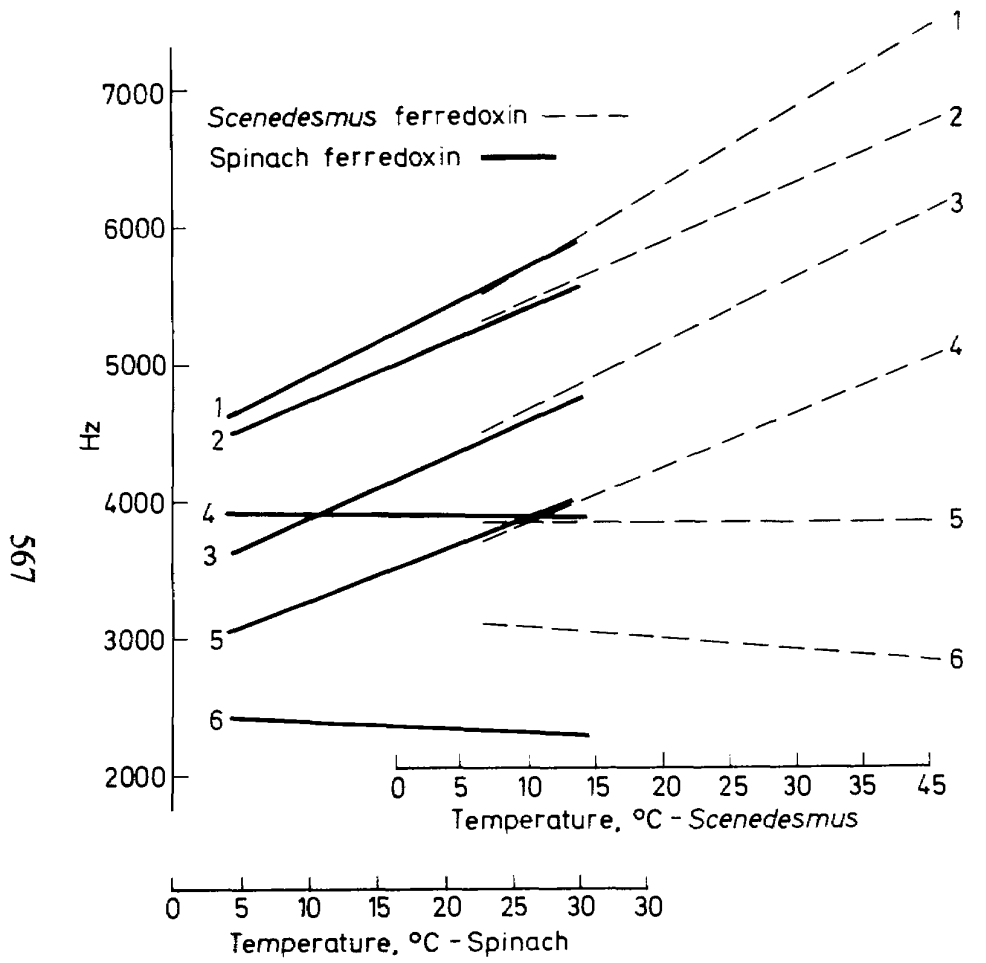

(i)

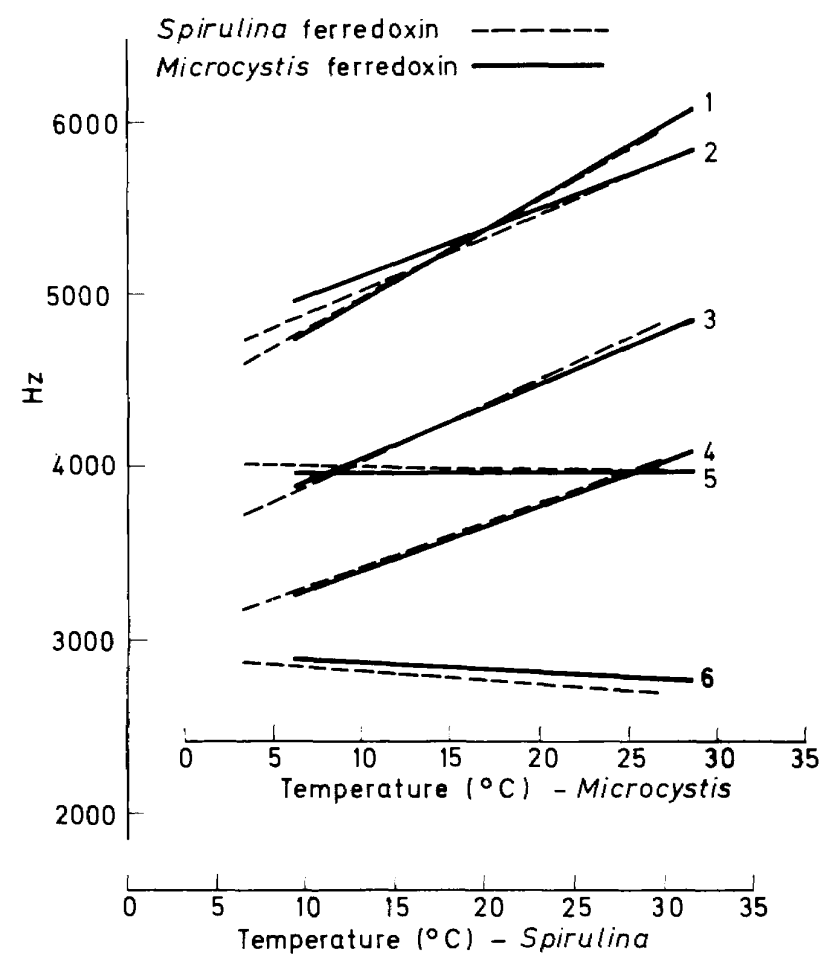

(b)

Figure 8. Temperature dependence of the low-field contact-shifted protons from reduced ferredoxins of (a) spinach and Scenedesmus and (b) Spirulina and Microcystis ferredoxins. The temperature scales have been offset to show the similarity of the patterns. Proton peaks are numbered as in Figure 7. (Unpublished results obtained in collaboration with W. D. Phillips and C. C. McDonald). 


\section{Proton magnetic resonance spectra}

Phillips and his associates have studied the proton magnetic resonance (pmr) spectra of spinach, parsley, alfalfa, and soyabean ferredoxins ${ }^{47,48}$. In order to measure the pmr spectra, the proteins were lyophilized, and dissolved under a nitrogen atmosphere in $0.2 \mathrm{M}$ Tris- $\mathrm{DCl}$ in 99.77 per cent $\mathrm{D}_{2} \mathrm{O}, \mathrm{P}_{\mathrm{d}}$ 7.8. Contact shifted resonances were detected to low field in the spectra of both oxidized and reduced ferredoxins (for example, see Figure 7). The resonances are assigned to the $\beta-\mathrm{CH}_{2}$ protons of the four cysteine residues that are thought to bind the iron--sulphur redox centre to the polypeptide chain. The temperature dependence of the contact shifts supported the proposal that the two iron atoms are antiferromagnetically coupled in both oxidized and reduced forms and the assignment for the valence states of high-spin $\mathrm{Fe}^{3+}-\mathrm{Fe}^{3+}$ and $\mathrm{Fe}^{2+}-\mathrm{Fe}^{3+}$ for the iron pairs in the oxidized and reduced ferredoxins. respectively. It seems that the temperature dependence of these contact shifts is very sensitive to protein structure. The whole pattern seems to be shifted at different temperatures in spinach with Scenedesmus (Figure $8 a$ ). The temperature dependent contact shifts of two bluegreen algal ferredoxins are compared in Figure $8 b$. Once again these indicate that while there is variation between the algal and higher plant ferredoxins the blue-green algal ferredoxins are very similar. Interestingly in the contact shift spectrum of reduced soyabean ferredoxin preparations it was possible to detect the presence of two distinct genetic variants in approximately equal concentration ${ }^{48}$. Thus pmr studies, in addition to being a valuable tool for the study of the nature of the paramagnetic species, can also be used to detect minor variations in the amino acid sequences of ferredoxins prepared from the same species.

\section{AMINO ACID SEQUENCES OF PLANT FERREDOXINS}

The primary structures of ferredoxins from five species of plants are known ${ }^{49}$. There is remarkable similarity in the structures from that of Scenedesmus (green alga) to Leuceana glauca (tree). These proteins consist of 96 or 97 amino acid residues and all of them have alanine at their amino terminal end. About 60 per cent of the residues are invariant in the five sequences. Other prominent similarities are. (1) that five cysteine residues are found in identical positions in all the ferredoxins sequenced; there is no cysteine in position 18 in Equisetum ferredoxin ${ }^{50}$ thus indicating that the other four invariant cysteines are involved in the binding of the two iron atoms in the active centre (Figure 5); (2) segments containing residues 18 to 26 , and 35 to 50 and 62 to 66 are invariant except for a substitution of Ala in residue 42 of Scenedesmus ferredoxin instead of Ser in all other ferredoxins. Though the sequences of other ferredoxins are not known, from their amino acid compositions and spectral properties we may assume close similarities in the primary structures of ferredoxins from the blue-green algae to higher plants. The primary structure of Scenedesmus ferredoxin is compared with that of spinach ferredoxin in Figure 9.

Blue-green algae are considered to be the most primitive algae, ecologically related. and evolutionarily close, to the photosynthetic bacteria since they 
(A) Ala Thr Tyr-Lys-Val-Thr-Leu-Lys-Thr-Pro-Ser Gly-Asp-Gln-Thr-Ile-Glu Cys-Pro-Asp-

(B) Ala- - la -Tyr-Lys-Val-Thr Leu-Val-Thr--Pro Thr-Gly-Asn-Val-Glu-Phe-Gin-Cys- Pro-Asp-

21

40

(A) Asp Thr Tyr Ile I.eu-Asp-Ala Ala Glu Glu-Ala Gly Iell Asp-Leu-Pro-Tyr Ser Cys-Arg-

(B) Asp- Val Iyr-Ile Leu -Asp-Ala-Ala Glu-Glu-Glu Gly Ile-Asp-Leu Pro Tyr-Ser- Cys- Arg.

41

(A) Ala-Gly Ala Cys-Ser-Ser- Cys-- Ala-Gly-Lys-Val-Glu-Ala-Gly-Thr -Val-Asp-Gln Ser Asp-

(B) Ala- Gly Ser-Cys- Ser-Ser- Cys- Ala-Gly-Lys-Leu-Lys-Thr-Gly-Ser-Leu-Asn-Gin-Asp-Asp-

61

(A) Gln-Ser-Phe I.cu Aøp Asp-Ser Gln Met-Asp-Gly-Crly-Phe Val-Leu-Thr Cys- $V a l-A l a-T y r-$

(B) GIn Sor Phe-Leu-Asp- Asp-Asp Gln-Ile-Asp Glu- Gly-Trp Val-Leu-Thr - Cys-Ala-Ala-Tyr

81

96

(A) Pro-Thr-Ser-Asp -Cys--Thr--Ile-Ala-Thr-His--Lys-Glu-Glu-Asp Leu Phe

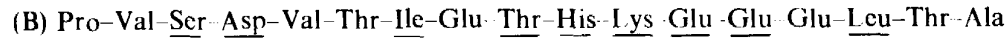

$=$ Invariant amino acids in all 5 sequenced plant ferredoxins ( 60 in all).

$\begin{array}{ll}\text { (A) Scenedesmus } & \text { (B) Spinach } \\ & \end{array}$

Figure 9. Sequences of plant ferredoxins.

do not have their photosynthetic pigments localized in chloroplasts and they are prokaryotes. Some blue-green algac like Spirulina $s p$. are essentially indistinguishable from some of the cyanophytes of microflora represented in the Bitter Springs (Australia) fossils believed to be about 900 million years of $\mathrm{age}^{51}$. But, like the green algae and higher plants (and unlike the photosynthetic bacteria), the blue-green algae liberate oxygen during photosynthesis and ferredoxin is an essential catalyst in the overall reaction. The amino acid composition and the nature of the active centre of ferredoxins from all species ranging from 'blue-greens' to higher plants are similar. It is probable that the development of the oxygen-evolving system and the concomitant development of plant-type ferredoxin marked the final stage in the evolution of the ferredoxin molecule from those of primitive bacteria (see later). The similarity of the ferredoxins in blue-green alga and in the chloroplasts of higher plants strongly supports the idea that chloroplasts are derived from the symbiotic association between a blue-green alga and a non-photosynthetic eukaryotic cell ${ }^{52.53}$.

\section{BACTERIAL AND MAMMALIAN FERREDOXINS CONTAINING TWO IRON ATOMS}

Iron-sulphur proteins resembling plant ferredoxins have been isolated from various bacterial and mammalian sources (Table 1). The active centre of these proteins containing two atoms of iron is almost identical to that of plant ferredoxins ${ }^{28,45,46,54}$. Of the former the primary structure of adrenodoxin $^{55}$, from mammalian adrenal $11 \beta$ steroid hydroxylase system, and of putidaredoxin ${ }^{56}$, a component of the camphor hydroxylase system of Pseudomonas putida, have been studied in detail. Putidaredoxin has 114 and 
(A) Ala-Ala-Tyr-Lys-Val-Thr-Leu-

(B) Ser-Ser-Ser-GIn-Asp-Lys-Ile-Thr-Val-His-Phe--Ile-Asn-Arg-Asp

8

(A) Val-Thr-Pro-Thr-Gily-Asn-Val-Glu-Phe-Gln-Cys-Pro-Asp-Asp-Val-Tyr-Ile-Leu-Asp-Ala-Ala-Glu-Glu-Glu-Gly-Ile-Asp-Leu-Pro-Tyr-

(B) Gly-Glu-Thr-Leu-Thr-Thr-Lys-Gly-Lys-Ile-Gly-Asp-Ser-Leu-Leu-Asp-Val-Val-Val-Gln-Asn-Asn-Leu-Asp-Ile-Asp-Gly-Phe-Gly-Ala-

(A) Ser-Cys-Arg-Ala-Gly-Ser- Cys-Ser-Ser-Cys-Ala-Gly-Lys-Leu-Lys-Thr-Gly-Ser-Leu-Asn-Gln-Asp-Asp-Gln-Ser-Phe-Leu-Asp-Asp-Asp-
(B) Cys-Glu-Gly-Thr-Leu-Ala Cys-Ser-Thr-Cys-His-Leu-Ile-Phe-Glu-Gln-His-Ile- Phe-Glu-Lys-Leu-Glu-Ala-Ile-Thr-Asn-Glu-Glu-AspO (B) Cys-Glu-Gly-Thr-Leu-Ala Cys-Ser-Thr-Cys-His-Leu-Ile-Phe-Glu-Gln-His-Ile- Phe-Glu-Lys-Leu-Glu-Ala-Ile-Thr-Asn-Glu-Glu-Asp-

68

(A) Gln-Ile-Asp-Glu-Gly-Trp-Val-Leu-Thr-Cys-Ala-Ala-Tyr-Pro-Val-Ser-Asp-Val-Thr-Ile-Glu-Thr-His-Lys-Glu-Glu-Glu-Leu-Thr-Ala-

(B) Asn-Met-Leu-Asp-Leu-Ala-Tyr-Gly Ile-Cys-Leu-Thr-Lys-Ala-Met-Asp-Asn-Met-Asp-Thr-Val-Arg-Val-Pro-Asp-Ala-Val-Ser-Asp-Ala

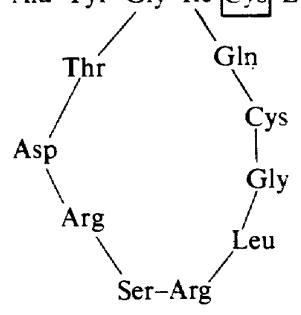

Figure 10. Comparison of spinach ferredoxin and adrenodoxin sequences.

(A) Spinach ferredoxin ${ }^{94}$, (B) Bovine adrenodoxin 55 
(A) Ala-Phe-Val-Ile-

(B) Ala-His-Ile-Ile-

Asn Asp-Ser- Cys-Val-Ser- Cys-Gly-Ala-Cys Ala-Gly-Glu Cys - Pro-Val-Ser-Ala-Ile-Thr-Gln-Gly-Asp-ThrThr-Asp-Gln- Cys-Ile-Ser- Cys-Gly-Ala-Cys-Ala-Ala-Glu-Cys-Pro-Val-Glu-Ala-Ile-His-Gln-Gly-Thr-Gly-

(C) Ala-Leu-Met-Ile-

Thr-Asp-Gln-

Cys-Ile-Asn

Cys-Asn-Val-Cys-Gln-Pro-Glu-Cys-Pro-Asn-Gly-Ala-Ile-Ser-Gin-Gly-Asp-Glu

(A) 29 Gln-Phe-Val-Ile-Asp-Ala-Asp-Thr-Cys-Ile-Asp- Cys-Gly-Asn-Cys-Ala-Asn-Val-Cys-Pro-Val-Gly-Ala-Pro-Asn-Gin-Glu

(B) Lys-Tyr-Gln-Val-Asp-Ala-Asp-Thr-Cys-Ile-Asp- Cys-Gly-Ala-Cys-Gln-Ala-Val-Cys-Pro-Thr-Gly-Ala-Val-Lys-Ala-Glu

(C) Thr-Tyr-Val-Ile-Glu-Pro-Ser-Leu- Cys-Thr-Glu-Cys-Val Asp Cys-Val-Glu-Val-Cys-Pro-Ile-Lys-Asp-Pro-Ser-His-Glu-Glu-Thr 29

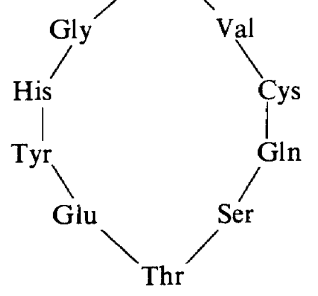

67

(C) Glu-Asp-Glu-Leu-Arg-Ala-Lys-Tyr-Glu-Arg-Ile-Thr-Gly-Glu-Gly

(A) C. butyricum: $:^{107}$ (B) C tartarivorum $:{ }^{61}$ (C) Chromatium : ${ }^{62}$

Figure 11. Comparison of sequences of Clostridium and Chromatium ferredoxins 
adrenodoxin 115 amino acid residues. In common with plant ferredoxins they contain at least one-Cys- $\mathrm{x}-\mathrm{x}-\mathrm{Cys}$ - grouping in their sequence. Tsai $e t$ $a l .{ }^{56}$ have identified a number of homologous segments in the primary structures of putidaredoxin and adrenodoxin and the sequences of these two ferredoxins exhibit a fair degree of similarity to the sequences of plant ferredoxins. We have aligned the sequences of adrenodoxin and spinach ferredoxin in Figure 10 to point out some of the similarities. A statistical analysis of various ferredoxin sequences by Barker et al. ${ }^{57}$ confirms the relationship between adrenodoxin and plant ferredoxins which suggests that all these ferredoxins could have evolved from a common ancestral gene. However, in spite of the identity of their active centre and similarity in their amino acid sequence, the two-iron ferredoxins of one type are not completely interchangeable with the two-iron ferredoxins of another type in their biological function. This could possibly be due to differences in their tertiary structures or due to differences in the structures of various reductases with which they combine during physiological electron transfer processes.

\section{FERREDOXINS CONTAINING EIGHT IRON ATOMS}

Ferredoxins cortaining eight atoms of iron have so far been obtained only from bacteria, both photosynthetic and non-photosynthetic. The optical absorption of these ferredoxins are characterized by a maximum at $390 \mathrm{~nm}$ and they differ in their biological action from the plant ferredoxins in that they transfer two electrons at a time. All these ferredoxins, thus far analyzed, except Chromatium ferredoxin, consist of about 55 amino acid residues with a molecular weight of approximately 6000 daltons. As in the plant ferredoxins the iron and 'labile sulphur' of these proteins can be removed by the action of reagents like trichloracetic acid and mercurials and the original ferredoxin can be reconstituted from the apoprotein by the addition of iron salt and sulphide in a reducing medium ${ }^{58}$. The structure of the iron-sulphur complex of this type of ferredoxin is not as well established as the plant ferredoxins. Magnetic susceptibility measurements have indicated strong antiferromagnetic exchange coupling between the component iron atoms in $C$. pasteurianum ferredoxin ${ }^{59}$. An $\mathrm{x}$-ray investigation of crystalline $M$. aerogenes ferredoxin has shown that the eight iron and sulphur atoms exist as two identical clusters of $4 \mathrm{Fe}$ plus $4 \mathrm{~S}$ at oms ${ }^{60}$. However, we still do not have enough information to correlate the magnetic resonance properties of these proteins and their electron transferring capacity.

The amino acid sequences of five ferredoxins from obligate fermentative bacteria are known ${ }^{61}$. In addition to the invariant positions of eight cysteine residues in the sequences of all these five ferredoxins there are many identical segments in their structures confirming the homologous nature of these proteins. The primary structure of Chromatium ferredoxin contains an extra 26 amino acid residues ${ }^{62}$. However, the similarity of this molecule to the other bacterial ferredoxins in this group is borne out by the invariant positions of many amino acid residues when its primary structure is realigned, as was done by Matsubara et al. ${ }^{63}$, and then compared with the clostridial ferredoxins. A similar comparison of Chromatium ferredoxin with two clostridial ferredoxins is depicted in Figure 11. 
(A) Ala-Phe-Val-Ile-Asn-Asp-Ser Cys-Val-Ser- Cys-Gly-Ala-Cys-Ala-Gly-Glu-Cys-Pro-Val-Ser-Ala- Ile-Thr-Gln-Gly-Asp- Thr (B) Pro-Ile-Gln-Val-Asp-Asn Cys-Met-Ala Cys-Gln-Ala Cys-Ile-Asn-Glu- Cys-Pro-Val-Asp-Val-Phe-Gln-Met-Asp-Glu-Gln-Gly-Asp-

\section{0} 17

(B) Lys-Ala-Val-Asn-Ile- Pro-Asn-Ser-Asn-Leu-Asp-Asp-Glu-Cys-Val-Glu-Ala-Ile-Gln-Ser-Cys-Pro-Ala-Ala-Ile-Arg-Ser (C) Glu-Gly-Ile-Asp-Leu-Pro-Tyr-Ser-Cys-Arg-Ala- Gly-Ser- Cys-Ser31

Figure 12. Sequence of D. gigas ferredoxin ${ }^{66}$ (B) compared with analogous segments of the ferredoxins of C. butyricum ${ }^{107}$ (A) and spinach ${ }^{94}$ (C). 


\section{THE FERREDOXINS CONTAINING FOUR IRON ATOMS}

Three ferredoxins containing four atoms each of iron and sulphur per molecule are fairly well characterized (Table 1). One of these, Chromatium high potential iron protein (HIPIP) is quite distinct in its properties from other ferredoxins ${ }^{64,65}$. No biological function has yet been found for this protein. The ferredoxin from the sulphate reducer Desulphovibrio gigas ${ }^{66}$ is interesting due to the fact that the primary structure of this protein is homologous in parts to segments of Clostridia ferredoxins and is similar in other parts to segments of plant ferredoxins (T. H. Jukes, personal communication). Their primary structures are compared in Figure 12. Bacillus polymyxa ferredoxin ${ }^{67}$ has a molecular weight of 9000 and on reduction accepts one electron per molecule ${ }^{68}$. These four-iron ferredoxins may be evolutionary links between the eight- and the two-iron ferredoxins and so are being actively studied by various groups.

\section{ARE FERREDOXINS PRIMITIVE PROTEINS?}

Ever since Oparin enunciated his theory about the abiogenic origin of life on earth attempts have been made to synthesize in the laboratory compounds like amino acids, purines, pyrimidines etc. under conditions which simulated prebiotic environments ${ }^{69}$. There is also a vigorous search to detect the presence of precursors of biological molecules like sugars, proteins and nucleic acids in extra-terrestrial matter ${ }^{70-72}$. The presence of these precursors in meteorites and other planets would indirectly prove their existence in the prebiotic earth's atmosphere. Amino acids like glycine, alanine, valine, glutamic acid, aspartic acid, proline, serine, cysteine and isoleucine have been synthesized under simulated primitive earth conditions ${ }^{49}$. Analysis of the Murchison and Murray meteorites and moon samples collected in the Apollo missions have shown the occurrence of the first six of the above-mentioned amino acids in these bodies. It is interesting that 64 per cent of $C$. butyricum ferredoxin is made up of these six amino acids. The clostridial ferredoxins are relatively small proteins and the iron and sulphur which form the active centre of these proteins can be added to the apoprotein by a non-enzymic process. They have a very low redox potential close to that of hydrogen gas. All these properties suggest the possibility that a ferredoxin-like protein would have functioned even in very primitive organisms.

\section{FERREDOXINS AS A TOOL IN PHYLOGENETIC CLASSIFICATION}

It is now a generally accepted thesis that any mutation in the nucleotide codons of the gene directing the synthesis of a particular protein will be expressed by an amino acid substitution in the sequence of the protein, i.e. the primary structures of homologous proteins are reflections of the nucleotide sequences of their genetic material. The ferredoxins are found in all species of organisms. The amino acid sequences of ferredoxins from five species of anaerobic bacteria are known and they show a high degree of homology. Also, the positions of certain key amino acids like the amino terminal alanine residue and the eight cysteine residues, which are thought to chelate the iron atoms, are identical in all these five ferredoxins. Thus these 


\section{EVOLUTION OF PLANT FERREDOXINS}

ferredoxins would probably have evolved from a common ancestral gene. The plant ferredoxins are about double the length of clostridial ferredoxins but the two groups show certain similarities in their properties and amino acid sequences. A quantitative comparison of the amino acid sequences of plant and Clostridia ferredoxins has indicated evolutionary relationships between these two groups but the evolutionary distances may be large ${ }^{57,63}$. The ferredoxin from the red photosynthetic bacterium Chromatium is intermediate in length between Clostridia and plant ferredoxins but in its sequence and function it is closer to the Clostridia type than to the plant ferredoxins. We do not yet know the complete sequence of a ferredoxin from a green photosynthetic bacteria. However, from the known amino acid composition and terminal residues of ferredoxins from this latter group we could predict that they are intermediate between the non-photosynthetic anaerobes and ihe red Chromatium ${ }^{73-75}$. The position of the sulphate reducer $D$. gigas is based on a comparison of the amino acid sequence of its ferredoxin with bacterial and plant ferredoxins (Figure 12) and on the suggestion of Schlegel ${ }^{75}$ from metabolic considerations that sulphate reducing bacteria can be placed between the anaerobic photolithotrophs (e.g. Chromatium) and the blue-green algae in the evolutionary ladder. Thus from a comparative study of the primary structure and function of ferredoxins from various species we could tentatively propose a phylogenic classification as outlined in Figure 13.

Anaerobic bacteria $\rightarrow$ Green photosynthetic bacteria $\rightarrow$ Red (sulphur) photosynthetic bacteria $\rightarrow$ julphate reducing bacteria (Desulphovibrio) $\rightarrow$ Algae

Figure 13. Evolutionary development of ferredoxins ${ }^{49}$.

\section{AKNOWLEDGEMENTS}

We thank the Science Research Council for grant support and Misses A. J. Cox and J. Zantovska for assistance.

\section{REFERENCES}

' L. E. Mortenson, R. C. Valentine and J. E. Carnahan, Biochem. Biophys. Res. Comm. 7, 488 (1962).

2 K. Tagawa and D. I. Arnon, Nature 195, 537 (1962).

3 D. I. Arnon, Experientia 22, 273 (1966).

${ }^{4}$ C. Nolan and E. Margoliash, Ann. Rev. Biochem. 37, 727 (1968).

5 J. E. Haber and D. E. Koshland, Jr., J. Mol. Biol. 50, 617 (1970).

6 P. Jolles and J. Jolles, Progr. Biophys. Mol. Bl. 22, 97 (1971).

7 R. E. Dickerson, J. Mol. Biol. 57, 1 (1971).

8 D. Boulter and J. A. M. Ramshaw, Phytochemistry 11, 553 (1972).

9 R. Malkin and J. C. Rabinowitz, Ann. Rev. Biochem. 36, 113 (1967).

${ }^{\circ}$ D. O. Hall and M. C. W. Evans, Nature 223, 1342 (1969).

1 B. B. Buchanan and D. I. Arnon, Advn. Enzymol. 33, 119 (1970).

2 K. K. Rao, R. Cammack, D. O. Hall and C. E. Johnson, Biochem. J. 122, 257 (1971).

${ }^{3}$ B. B. Buchanan and D. I. Arnon, Methods in Enzymology 23, 413 (1971).

4 K. Sugeno and H. Matsubara, J. Biol. Chem. 244, 2979 (1969).

5 F. R. Whatley, K. Tagawa and D. I. Arnon, Proc. Natl. Acad. Sci. U.S. 49, 266 (1963).

6 M. C. W. Evans, D. O. Hall, H. Bothe and F. R. Whatley, Biochem. J. 110, 485 (1968).

7 M. Losada, A. Paneque, J. M. Raminez and F. F. Del Campo. Biochem. Biophys. Res. Comm. 10, 298 (1963). 
18 A. San Pietro, Meth. Enz. 6, 439 (1963).

19 E. Bayer, J. D. Krauss. P. Hagenmaier, H. Roder and A. Trebst. Biochim. Biophys, Acta 143. $435(1967)$.

20 S. Keresztes-Nagy, F. Perini and E. Margoliash. J. Biol. Chem. 244, 981 (1969).

21 D. Petering, J. A. Fee and G. Palmer, J. Biol. Chem. 246, 643 (1971).

22 K. R. Garbett, R. D. Gillard, P. K. Knowles and J. E. Stangroom. Nature 215, 824 (1967).

23 R. Padmanabhan and T. Kimura. J. Biol. Chem. 245, 2469 (1970).

24 D. H. Petering and G. Palmer. Arch. Biochem. Biophys. 141, 456 (1970).

25 R. Cammack. K. K. Rao and D. O. Hall, Biochem. Biophys. Res. Comm. 44, (1971).

26 N. Nelson and J. Neumann, Biochem. Biophys. Res. Comm. 30, 142 (1968).

27 R. Cammack, J. Neumann. N. Nelson and D. O. Hall. Biochem. Biophys. Res. Comm. 42, 292 (1971).

28 W. A. Eaton, G. Palmer, J. A. Fee. T. Kimura and W. Lovenberg, Proc. Natl. Acad. Sci. U.S. 68, 3015 (1971).

29 (i. Palmer and R. H. Sands, J. Biol. Chem. 241, 253 (1966).

30 D. O. Hall, J. F. Gibson and F. R. Whatley, Biochem. Biophys. Res. Comm. 23, 81 (1966).

31 W. H. Orme-Johnson and H. Beinert, J. Biol. Chem. 244, 6143 (1969).

32 G. Palmer. Biochem. Biophys. Res. Comm. 27, 315 (1967).

${ }^{33}$ C. E. Johnson, R. Cammack. K. K. Rao and D. O. Hall, Biochem. Biophys. Res. Comm. 43, $564(1971)$.

34 J. A. Fee and G. Palmer, Biochim. Biophys. Acta 245, 175 (1971).

35 J. C. M. Tsibris and R. W. Woody, Coord. Chem. Rev. 5, 417 (1970).

36 R. E. Coffman and B. W. Stevens, Biochem. Biophys. Res. Comm. 41, (1970).

37 D. O. Hall, K. K. Rao and R. Cammack, Biochem. Biophys. Res. Comm. 47, 798 (1972).

38 J. F. Gibson. D. O. Hall, J. H. M. Thornley and F. R. Whatley, Proc. Natl. Acad. Sci. U.S. 56. $987(1966)$.

34 J. H. M. Thornley, J. F. Gibson, F. R. Whatley and D. O. Hall, Biochem. Biophys. Res. Comm. 24. 877 (1966).

40 W. D. Phillips, E. Knight and D. C. Blomstrom in Non-heme iron proteins. (A. San Pietro, ed.), p. 69. Antioch Press, Ohio (1965).

41 G. Lang. Quart. Rev. Biophys. 3, 1 (1970).

42 C. E. Johnson in Magnetic Resonance in Biological Systems, (A. Ehrenberg, B. G. Malmström and T. Vängard, eds.). p. 405. Pergamon Press, Oxford (1967).

43 C. E. Johnson, J. Appl. Phys. 42, 1325 (1971).

44 C. E. Johnson, E. Elstner, J. F. Gibson, G. Benfield, M. C. W. Evans and D. O. Hall, Nature 220. 1291 (1968).

45 R. Cammack. D. O. Hall, K. K. Rao and C. E. Johnson, Biochem. J. 125, 849 (1971).

46 W. R. Dunham, A. J. Bearden, I. T. Salmeen. R. H. Sands, W. H. Orme-Johnson and H. Beinert. Biochim. Biophys. Acta 253, 134 (1971).

47 M. Poe, W. D. Phillips, J. D. Glickson, C. C. McDonald and A. San Pietro, Proc. Natl. Acad. Sci. U.S. 68, 68 (1971).

48 J. D. Glickson. W. D. Phillips, C. C. McDonald and M. Poe, Biochem. Biophys. Res. Comm. 42, 271 (1971).

49 D. O. Hall. R. Cammack and K. K. Rao in Theory and Experiment in Exobiology, Vol. 2, (A. Schwartz, ed.) p 67, Wolters-Noordhof, Netherlands (1972).

50 S. J. Aggarwal, K. K. Rao and H. Matsubara, J. Biochem. (Tokyo), 69, 601 (1971)

51 J. W. Schopf, Biol. Rev. 45, 319 (1970).

52 L. Sagan, J. Theoret. Biol. 14, 225 (1967).

53 D. O. Hall, R. Cammack and K. K. Rao, Nature 233, 136 (1971).

54 E. Munck, P. G. Debrunner, J. C. M. Tsibris and I. C. Gunsalus, Biochemistry 11, 855 (1972).

55 M. Tanaka, M. Haniu and K. T. Yasunobu, Biochem. Biophys. Res. Comm. 39, 1182 (1970).

56 R. L. Tsai, I. C. Gunsalus and K. Dus. Biochem. Biophys. Res. Comm. 45, 1300-1306 (1971).

57 W. C. Barker, P. J. McLaughlin and M. O. Dayhoff, Fed. Proc. 31, 837 Abs (1972).

58 R. Malkin and J. C. Rabinowitz, Biochem. Biophys. Res. Comm. 32, 822 (1966).

${ }^{59}$ M. Poe, W. D. Phillips, C. C. McDonald and W. Lovenberg, Proc. Natl. Acad. Sci. U.S. 65, 798-804 (1970).

60) L. C. Sieker, E. Adman and L. H. Jensen, Nature 235, 40 (1972).

61 M. Tanaka, M. Haniu, G. Matsueda, K. T. Yasunobu, R. H. Himes, J. K. Akagi, E. M. Barnes and T. Devanathan, J. Biol. Chem. 246, 3953 (1971). 


\section{EVOLUTION OF PLANT FERREDOXINS}

${ }^{62}$ H. Matsubara, R. K. Sasaki, D. K. Tsuchiya and M. C. W. Evans, J. Biol. Chem. 245, 2121 (1970).

63 H. Matsubara, T. H. Jukes and C. R. Cantor, Brookhaven Symp. Biol. 21, 201 (1968).

64 K. Dus, H. De Klerk, K. Sletten and R. G. Bartsch, Biochim. Biophys. Acta. 140, 291 (1967).

65 K. Dus, S. Tedro, R. G. Bartsch and M. D. Kamen, Biochem. Biophys. Comm. 43, 1239 (1971).

66 J. Travis, D. J. Newman, J. Le Gall and H. D. Peck, Biochem. Biophys. Res. Comm. 45, 452 (1971).

67 Y. I. Shethna, N. A. Stombaugh and R. H. Burris, Biochem. Biophys. Res. Comm. 42, 1108 (1971).

68 W. H. Orme-Johnson, N. A. Stombaugh and R. H. Burris. Fed. Proc. 31, 448 Abs. (1972).

69 D. H. Kenyon and G. Steinman, Biochemical Predestination. McGraw-Hill, N.Y. (1969).

${ }^{70}$ K. A. Kvenvolden, J. G. Lawless, K. Pering, E. Peterson, J. Flores, C. Ponnamperuma, I. R. Kaplan and C. Moore, Nature 228, 923 (1970).

71 J. G. Lawless, C. E. Folsome and K. A. Kvenvolden, Sci. Amer., 226(b), 38 (1972).

72 K. Harada, P. G. Hare, C. R. Windsor and S. W. Fox, Science 173, 433 (1971).

${ }^{73}$ B. B. Buchanan, H. Matsubara and M. C. W. Evans. Biochim. Biophys. Acta. 189, 46 (1969).

${ }^{74}$ K. K. Rao, H. Matsubara, B. B. Buchanan and M. C. W. Evans, J. Bacteriology 100, 1411 (1969).

75 H. G. Schlegel, Intl. Symp. Origin of Life and Evolutionary Biochemistry, Varna, Bulgaria (1971).

70 J. S. Hong and J. C. Rabinowit/, J. Biol. Chem. 245, 4982 (1970).

77 M. Tanaka, T. Nakashima, A. M. Benson, H. F. Mower and K. T. Yasunobu, Biochemistry 5, $1666(1966)$.

78 G. Palmer, R. H. Sands and L. E. Mortenson, Biochem. Biophys. Res. Comm. 23, 357 (1966).

79 K. T. Shanmugam, B. B. Buchanan and D. I. Arnon, Biochim. Biophys. Acta. 256, 477 (1972).

80 R. Bachofen and D. I. Arnon, Biochim. Biophys. Acta. 120, 259 (1966).

81 D. C. Yoch, J. R. Benemann, R. C. Valentine and D. I. Arnon, Proc. Natl. Acad. Sci. U.S. 64, $1404(1969)$.

82 D. V. Dervartanian, Y. I. Shethna and H. Beinert, Biochim. Biophys. Acta. 194, 548 (1969).

83 Y. I. Shethna, Biochim. Biophys. Acta 205, 58 (1970).

84 K. A. Davis and Y. Hatefi, Biochemistry 10, 2509 (1971).

${ }^{85}$ S. G. Mayhew, D. Petering, G. Palmer and G. P. Foust, J. Biol. Chem. 244, 2830 (1969).

${ }^{86}$ R. W. F. Hardy, E. Knight, C. C. McDonald and A. J. D'Eustachio in Non-heme iron proteins. (A. San Pietro, ed.), p. 275. Antioch Press, Ohio (1965).

87 G. Nakos and L. E. Mortenson, Biochemistry 10, 455 (1971).

88 G. Nakos and L. E. Mortenson. Biochemistrv 10. 2442 (1971).

89 J. S. Multani and L. E. Mortenson, Biochim. Biophys. Acta 256, 66 (1972).

90 Y. I. Shethna, D. V. Dervartanian and H. Beinert, Biochem. Biophys. Res. Comm. 31, 862 (1968).

91 H. Vetter and J. Knappe, Hoppe-Seyler's Z. Physiol. Chem. 352, 433 (1971).

92 K. K. Rao, R. V. Smith, R. Cammack, M. C. W. Evans, D. O. Hall and C. E. Johnson, Biochem J. 129, 1159 (1972).

93 A. Mitsui and D. I. Arnon, Physiol. Plant. 25, 135 (1971).

94 H. Matsubara and R. M. Sasaki, J. Biol. Chem. 243, 1732 (1968).

95 T. Kimura, Struct. and Bond. 5, 1 (1968).

96 J. S. Rieske in Non-heme iron proteins. (A. San Pietro, ed.), p. 461. Antioch Press, Ohio (1965).

${ }^{77}$ T. Yamanaka, S. Takenami, K. Wada and K. Okunuki, Biochim. Biophys. Acta 180, 196 (1969).

98 P. Böger, Planta 92, 105 (1970).

99 A. Mitsui, Biochim. Biophys. Acta 243, 447 (1971).

100 A. A. Mutuskin, K. V. Psheneva, G. P. Kaverina and P. A. Kolesnikov, Doklady Akad. Nauk. SSSR 183, 715 (1968).

101 P. Schürmann, B. B. Buchanan and H. Matsubara, Biochim. Biophys. Acta 223, 450 (1970).

102 C. G. Crawford and R. G. Jensen, Plant Physiology 47, 447 (1971).

103 S. S. Lee, J. Travis and C. C. Black, Jr. Arch. Biochem. Biophys. 141, 676 (1970).

104 K. K. Rao and H. Matsubara, Biochem. Biophys. Res. Comm. 38, 500 (1970).

105 D. J. Newman, J. N. Ihle and L. Dure, Biochem. Biophys. Res. Comm. 36, 947 (1969).

106 A. M. Benson and K. T. Yasunobu, J. Biol. Chem. 244, 955 (1969).

107 A. M. Benson, H. F. Mower and K. T. Yasunobu, Arch. Biochem. Biophys. 121, 563 (1967). 